Article

\title{
Impact of Clay Minerals on the Dewatering of Coal Slurry: An Experimental and Molecular-Simulation Study
}

\author{
Xiaomin Ma, Yuping Fan *(D), Xianshu Dong *, Ruxia Chen, Hongliang Li, \\ Dong Sun and Suling Yao \\ College of Mining Engineering, Taiyuan University of Technology, Taiyuan 030024, Shanxi, China; \\ near0369@163.com (X.M.); ruxiachen0828@163.com (R.C.); lihongliang222@126.com (H.L.); \\ near0369@126.com (D.S.); yaosuling@tyut.edu.cn (S.Y.) \\ * Correspondence: 19880628fyp@163.com (Y.F.); dxshu520@163.com (X.D.)
}

Received: 31 July 2018; Accepted: 5 September 2018; Published: 11 September 2018

check for updates

\begin{abstract}
The cleaning process of coals is challenging due to the existence of clay minerals. The overall objective of this study is to investigate how the dewatering of coal slurry is impacted by the presence of clay minerals, i.e., kaolinite and montmorillonite. Filtration tests were first conducted to investigate the effect of kaolinite and montmorillonite on the dewatering efficiency of coal. Specifically, we measured the filtration velocity, moisture, average specific resistance, and porosity of filter cakes for six slurry samples, in which different amounts of kaolinite and montmorillonite were contained. Filtration tests show that a small amount of kaolinite and montmorillonite leads to a significant reduction in the filtration velocity and porosity, and a big increase in the average specific resistance and the moisture of the filter cake. We observe that most kaolinite existed in the top and middle layers of the filter cake, while most montmorillonite existed in the top layer; on the contrary, little montmorillonite is observed in the middle and bottom layers of the filter cake. Montmorillonite results in a much more deteriorative effect than kaolinite. Considering that the interactions between clay minerals and water may play a key role, we then further investigate the effect of such interactions using molecular simulations. Simulation results show that water molecules could hardly diffuse into kaolinite from the edge, while they could readily penetrate into the montmorillonite layers from the edge surface. This result can be explained by the hydrated cation in montmorillonite. The adsorption density of water on the octahedral surface of kaolinite is higher than that of water on the tetrahedral surface of kaolinite. Furthermore, the adsorption density of water on the double surfaces of kaolinite is higher than that of water on the montmorillonite surface. This research is expected to provide benefits or contributions to the dewatering of clay-rich coal tailings.
\end{abstract}

Keywords: coal tailings; dewatering; montmorillonite; kaolinite; molecular simulation

\section{Introduction}

The cleaning process of coals is generally associated with a significant amount of tailings in the coal preparation plant. Proper disposal of these coal tailings has both environmental and economic benefits through the recovery of fine coals and the reuse of processed water [1]. The fine coal tailings generally contain $20-40 \%$ clay minerals in the coal preparation plant $[2,3]$. Flocculation and the subsequent dewatering method are key links in the treatment process [4,5]. In other coal-related industries, such as coal mining [6,7] and coal bed methane (CBM) production [8-10], the treatment of underground or produced water is also of great significance. The water is characterized by high salinity and is rich in fine coal particles, as well as incorporated clay minerals. Furthermore, the existence of clay 
minerals usually makes it challenging to improve the efficiency of processes related to solid-liquid separation [11-13].

The most common clay minerals encountered in coal and tailings water are kaolinite, montmorillonite, illite, or mixed-layer illite/montmorillonite clays [4,6]. Kaolinite and montmorillonite are two representative types of clay minerals in terms of structural properties. Kaolinite is a 1:1 aluminosilicate consisting of a tetrahedral silica sheet and an octahedral alumina sheet [14]. Montmorillonite is a 2:1 layer silicate consisting of two tetrahedral silica sheets with an octahedral alumina sheet sandwiched between the two silica sheets. Kaolinite is a nonswelling clay and montmorillonite is a swelling clay [15]. The swelling properties and water-clay interaction have received extensive attention and are considered to be the most influential factors affecting the dewatering of clay-related materials [16-20]. Foster [21] investigated the relationship of composition and swelling in clays. They suggested that montmorillonite contributes to clay swelling by the following mechanism: montmorillonite has a permanent high negative charge that is balanced by an exchangeable hydrated cation $\left(\mathrm{Na}^{+}, \mathrm{Ca}^{2+}\right.$, etc.) because of the isomorphous substitution such as $\mathrm{Mg}$ replacing $\mathrm{Al}$ in the alumina layer. Segad et al. $[22,23]$ studied the swelling properties of montmorillonite; they found that the swelling properties were affected by ion type, temperature, etc. McFarlane et al. [20,24,25] researched methods to improve the dewatering of kaolinite and montmorillonite to solve challenges caused by clay minerals, especially montmorillonite, in industrial solid-liquid separation processes.

Previous studies also showed that the clay-based coal or oil tailings have poor solid-liquid separation efficiency [26-28]. Rong et al. [29] conducted a survey of the dewatering behaviors on slurry samples from 27 Australian coal preparation plants. Their results showed that the coals containing more kaolinite tend to produce less moisture in the filter cake. They concluded that the other minerals in the coals may have a more significant impact on the dewatering efficiency than kaolinite. Hussian et al. [30] found that clay harmfully affects coal washing processes, such as flotation, flocculation, and dewateing. They studied the zeta potential of clays and the effects of clays on coal flotation. Alam et al. [31] and Ofori et al. [27] studied the dewatering performance of clay-rich coal tailing under the action of varying coagulant/flocculant, dosage, and mechanical shearing conditions. The negative effect of clay minerals on the dewatering of coal tailings has been widely reported in previous works [32-35]. However, limited studies are reported on how to quantitatively evaluate the impact of kaolinite and montmorillonite on the dewatering efficiency as well as the mechanisms.

The objective of this study is to quantitatively evaluate the effect of kaolinite and montmorillonite on the dewatering of coal slurry and interpret the physics of water-clay interactions. We first conducted the filtration experiments to evaluate the effect of the content of kaolinite and montmorillonite on filtration efficiency. We then run molecular simulations based on an accurate force field (PCFF-INTERFACE [36]) to explore the mechanisms of interactions of kaolinite and montmorillonite with water. This research is expected to provide benefits or contributions to the dewatering of clay-rich coal tailings.

\section{Materials and Methods}

\subsection{Materials}

In the experiments, the coal we used was collected from a coal separation plant located in Changzhi, Shanxi Province, China. Tables 1 and 2 summarize the characteristics of the coal including approximate properties and particle-size distributions, respectively. It was a high-rank bituminous coal.

Table 1. Proximate analysis of the coal sample.

\begin{tabular}{cccccc}
\hline Sample & Moisture (\%) & Ash (\%) & Volatile Matter (\%) & Fixed Carbon (\%) & Density $\left(\mathrm{g} / \mathrm{cm}^{\mathbf{3}}\right)$ \\
\hline Coal & 1.21 & 14.59 & 12.22 & 71.98 & 1.42 \\
\hline
\end{tabular}


Table 2. Particle size distribution of the coal sample.

\begin{tabular}{ccccc}
\hline \multirow{2}{*}{ Size Classes (mm) } & \multirow{2}{*}{ Mass Fraction (\%) } & Ash Content (\%) & \multicolumn{2}{c}{ Accumulation } \\
\cline { 4 - 5 } & & & Mass Distribution (\%) & Ash Content (\%) \\
\hline $0.25-0.5$ & 6.56 & 12.64 & 6.45 & 12.64 \\
$0.125-0.25$ & 15.76 & 11.34 & 22.32 & 11.72 \\
$0.075-0.125$ & 22.68 & 13.53 & 45.01 & 12.63 \\
$0.045-0.075$ & 13.32 & 13.79 & 58.32 & 12.90 \\
-0.045 & 41.68 & 17.02 & 100.00 & 14.62 \\
Total & 100.00 & 14.62 & & \\
\hline
\end{tabular}

Kaolinite and Na-rich montmorillonite samples (99\%) were purchased from Lingshou Yu Mineralization Products Processing Co. Ltd. in Shijiazhuang, Hebei Province, China. Figure 1 shows the particle-size distribution of kaolinite and montmorillonite, measured by the Mastersizer 3000 laser particle size analyzer (Malven Instruments, Malvern, Worcestershire, UK). Before sending them for particle analysis, the clay suspensions were fully dispersed by ultrasound for $10 \mathrm{~min}$. The median diameter $\left(d_{50}\right)$ of kaolinite and montmorillonite particles was $6.34 \mu \mathrm{m}$ and $9.77 \mu \mathrm{m}$, respectively.

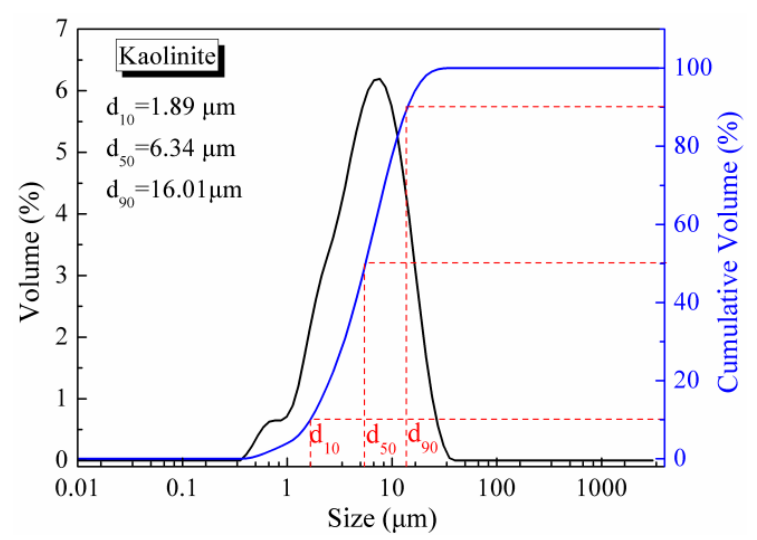

(a)

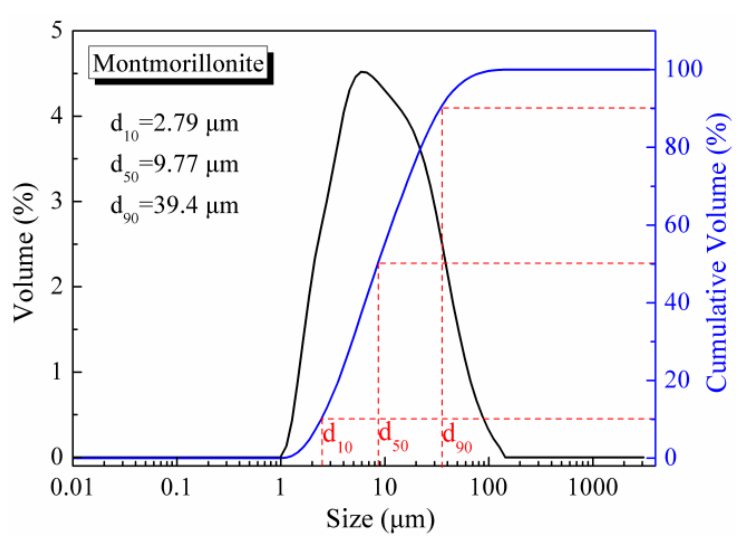

(b)

Figure 1. Particle size distribution of (a) kaolinite and (b) montmorillonite.

\subsection{Filtration Experiments}

We used Büchner funnel filtration equipment as published by Fan et al. [37] to carry out the filtration experiments. A schematic of the device is shown in Figure 2. The solid concentration of all prepared slurry samples was $200 \mathrm{~g} / \mathrm{L}$. The procedure is summarized as follows: (1) The slurry sample was mixed for $5 \mathrm{~min}$ at $300 \mathrm{rpm}$ before each filtration experiment. (2) We then opened the vacuum pump and set the pressure at $4 \pm 0.1 \mathrm{kPa}$, and quickly put a $100 \mathrm{~mL}$ slurry sample into the Büchner funnel. Standard quantitative filter paper with a pore size of $2 \mu \mathrm{m}$ and a diameter of $9 \mathrm{~cm}$ was used. (3) The filtrate volume and time interval were recorded to calculate the filtration velocity. (4) The filtration test was stopped after $30 \mathrm{~min}$ when there was no water being recovered. (5) Generally, the thickness of the filter cake ranged from $6 \mathrm{~mm}$ to $10 \mathrm{~mm}$. We then cut the filter cake into several pieces and dried them in an oven at $105^{\circ} \mathrm{C}$ for $24 \mathrm{~h}$.

The image of the filter cake was taken by an ANDONSTAR A7 digital microscope (Andonstar Tech Co., Ltd., Shenzhen, China). Then, ImageJ and MATLAB software (Version R2012a) (MathWorks Inc., Massachusetts, MA, USA) were used to measure and calculate the porosity. We calculated the contents of moisture and ash of three parts of filter cakes to investigate the distribution of kaolinite, montmorillonite, and water. As described in Equation (1), we used Ruth's theory [38] to determine the average specific resistance of the filter cakes. 


$$
u=\frac{d V}{A d t}=\frac{\Delta P(1-m s) A}{\mu \alpha_{a v}\left(V+V_{m}\right) \rho s}
$$

where $u$ is the filtration velocity, $V$ is the filtrate volume, $V_{m}$ is the equivalent filtrate volume, $t$ is filtration time, $A$ is the effective filtration area, $\mu$ is the viscosity of the filtrate, $\Delta P$ is the filtration pressure, $m$ is the solid /water ratio, $s$ is the solid concentration, $\rho$ is the density of the filtrate $\left(\mathrm{kg} / \mathrm{m}^{3}\right)$, and $\alpha_{a v}$ is the average specific cake resistance. The calculation procedure has been described in detail elsewhere [39].

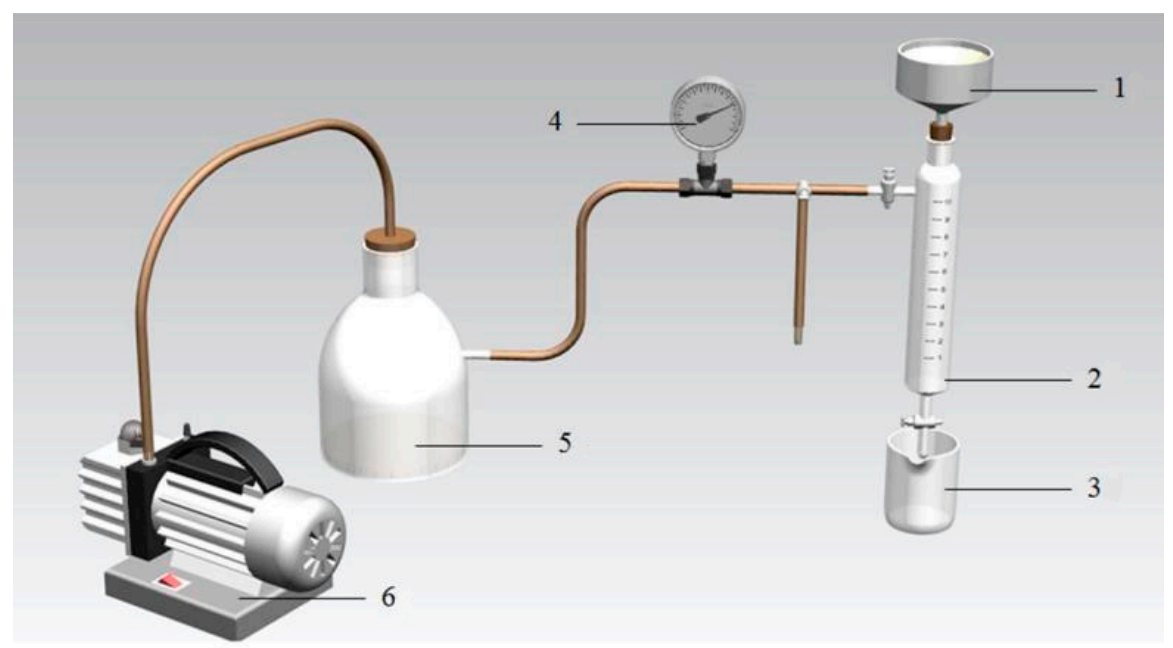

Figure 2. Büchner funnel filtration equipment [18]. 1-Büchner funnel; 2-Filter tube; 3-Filtratre collector; 4-Vacuum pressure gauge; 5-Buffer bottle; 6-Vacuum pump. (Reproduced with permission from Fan et al. [37]; published by Elsevier, 2015).

\subsection{Molecular Simulation}

Water-clay interactions were studied for their importance in affecting the dewatering of clay-related matters [24]. We conducted molecular dynamic simulations for water-kaolinite/ montmorillonite systems using the Forcite module in Materials Studio 8.0 (BIOVIA Corp., San Diego, CA, USA). All simulations were based on the PCFF-INTERFACE force field. This force field has been proved to be accurate in simulating kaolinite and montmorillonite [40].

Figure 3 shows the basic model structures of kaolinite and montmorillonite, respectively. The chemical formula of the kaolinite model can be described as $\mathrm{Al}_{2} \mathrm{Si}_{2} \mathrm{O}_{5}(\mathrm{OH})_{4}$. We used a Na-montmorillonite model to represent montmorillonite, which is consistent with the Na-montmorillonite used in the filtration experiments. This Na-montmorillonite model is built by the isomorphous substitutions of $\mathrm{Mg}$ atoms replacing several $\mathrm{Al}$ atoms in the octahedral sheet. Furthermore, $\mathrm{Na}^{+}$was added to the layers to compensate charge. The general chemical formula for the montmorillonite model could be described as $\mathrm{Na}_{0.75}\left[\mathrm{Mg}_{0.75} \mathrm{Al}_{3}\right]\left(\mathrm{Si}_{4} \mathrm{O}_{10}\right)_{7.5}(\mathrm{OH})_{3.75}$.

The size of a single layer of kaolinite and montmorillonite used in the simulation was about $2.7 \times 2.5 \mathrm{~nm}$ in the $\mathrm{X}$ and $\mathrm{Y}$ directions. We performed geometry minimization and molecular dynamic (MD) simulations under fine-quality settings in the software. The isobaric-isothermal ensemble (NPT) or canonical ensemble (NVT) were used for the equilibrium of different model systems. The short-range van der Waals interactions were truncated at $15.5 \AA$, and the long-range electrostatics interactions were calculated with the Ewald summation method (accuracy of $1 \times 10^{-4} \mathrm{kcal} / \mathrm{mol}$ ). The time step was $1 \mathrm{fs}$. We controlled the system temperature and pressure using a Nosé-Hoover thermostat and Berendsen barostat, respectively. Generally, we ran the simulation at least 500 ps NPT (at $298 \mathrm{~K}, 1 \mathrm{~atm}$ ) to reach equilibrium, and then recorded the data in the other $200 \mathrm{ps} \mathrm{NVT}$ at the same pressure and temperature.

Equations (2) and (3) show the method of calculating the $d$-spacing and the diffusion coefficient, respectively. We calculated the $d$-spacing by applying Bragg's law on X-ray diffraction (XRD) profiles, 
which was obtained using the Reflex tool in Materials Studio, with a copper X-ray source (wavelength at $1.54 \AA$ ) at a $2 \theta$ range of $1-45^{\circ}$. Equation (2) describes Bragg's law [41].

$$
n \lambda=2 d_{h k l} \sin \theta_{h k l}
$$

where $n$ is a positive integer (here it is 1 ); $\lambda$ is the wavelength of the copper $X$-ray; $h, k, l$ are the Miller indices of the Bragg plane, and $d_{h k l}$ is the interlayer distance.

As shown in Equation (3), the diffusion coefficient is obtained using its relationship with the mean square displacement (MSD) [42].

$$
D=\frac{1}{6} \lim _{\Delta t \rightarrow \infty} \frac{d M S D}{d \Delta t}
$$

where $D$ is the diffusion coefficient, and $\lim _{\Delta t \rightarrow \infty} \frac{d M S D}{d \Delta t}$ could be obtained from the slope of the MSD-time curve.

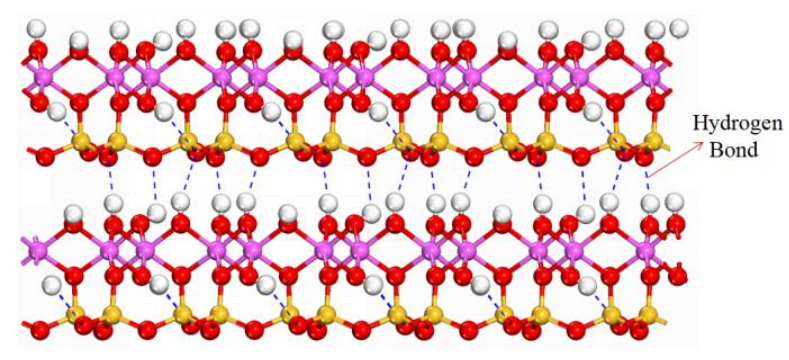

(a)

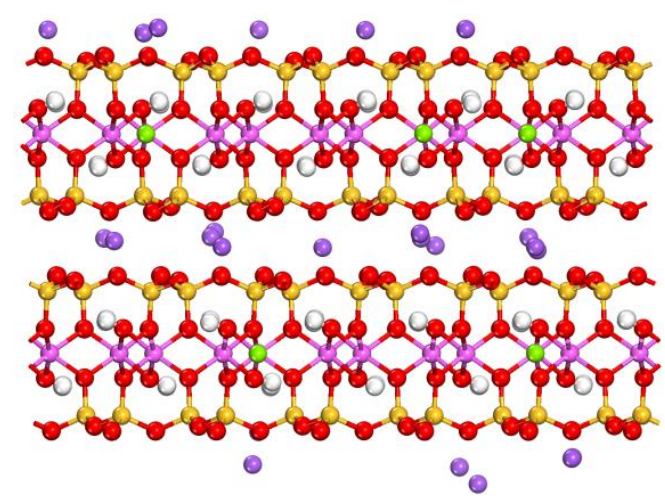

(b)

Figure 3. Structures of (a) kaolinite and (b) montmorillonite.

\section{Results and Discussion}

\subsection{Filtration Experiment Results}

\subsubsection{Filtration Velocity}

Filtration velocity is quite an important indicator to evaluate the dewatering of tailing in laboratory experiments. Generally, it is illustrated by the slope of the filtrate volume-time curves. As shown in Figure $4 \mathrm{a}$, the curve slopes related to slurries containing certain proportions of clay minerals were lower than the curve slope related to pure coal. This means that the filtration velocity decreased with the increasing content of kaolinite and montmorillonite. We also observed a much lower filtration velocity in cases with montmorillonite compared to cases with kaolinite. This observation suggests that montmorillonite contributed to a more significant reduction in filtration velocity than kaolinite. When the content of montmorillonite was up to $5 \%$ or $10 \%$, the filtration became quite slow and needed a lot of time to reach completion.

\subsubsection{Moisture}

Figure $4 \mathrm{~b}$ shows the moisture results of cakes. In Figure $4 \mathrm{~b}$, we observed that the two cases with montmorillonite ( $5 \%$ and $10 \%$ content) showed relatively higher moisture in the filter cake than the remaining five cases. The moisture of the cake with $100 \%$ coal was $21.26 \%$. However, the moisture of cakes containing $10 \%$ kaolinite and $10 \%$ montmorillonite were $24.38 \%$ and $41.99 \%$, respectively. The figure shows a significant increase in moisture when increasing the amount of montmorillonite, whereas the increase in moisture was small with increasing kaolinite. The presence of only $5 \%$ 
montmorillonite in slurry could make it quite difficult to expel water from the cake; thus, it severely hindered the dewatering performance.

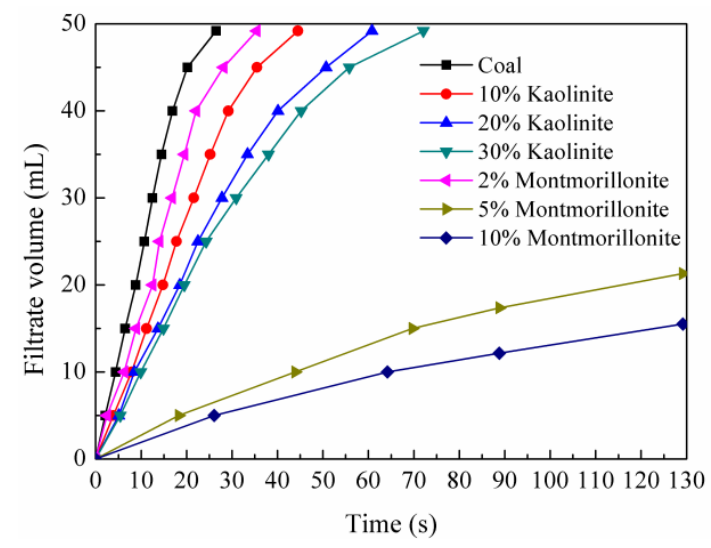

(a)

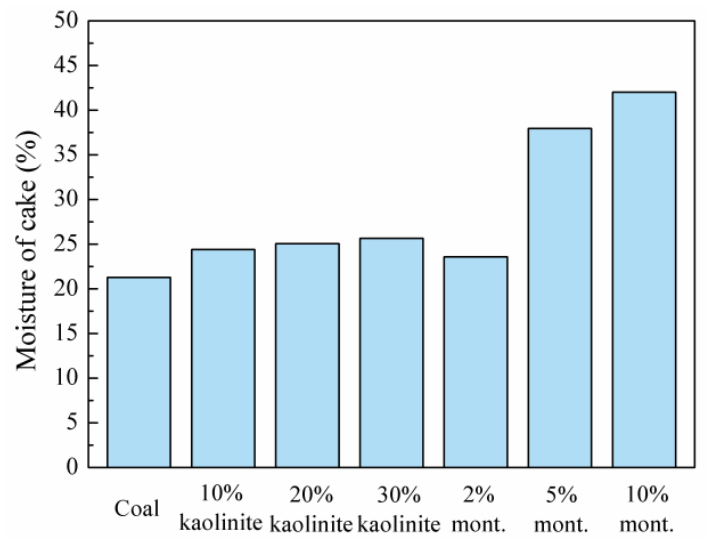

(b)

Figure 4. (a) Filtrate volume as a function of time, and (b) moisture of the filter cake for dewatering of coal slurries with different contents of kaolinite and montmorillonite.

\subsubsection{Average Specific Resistance}

Average specific resistance is a parameter of fundamental importance to quantitatively compare the filterability of different types of slurry samples, which has a sound theoretical basis $[43,44]$. Table 3 shows that the average specific resistance of raw coal was $1.98 \times 10^{7} \mathrm{~m} / \mathrm{kg}$, indicating a good filterability of the coal sample. The mixture of coal and clays showed a higher average specific resistance. As the content of kaolinite increased from $10 \%$ to $30 \%$, the average specific resistance increased from $2.35 \times 10^{8}$ to $4.51 \times 10^{8} \mathrm{~m} / \mathrm{kg}$. For montmorillonite, as its content increased from $2 \%$ to $10 \%$ in slurry, the average specific resistance increased from $4.30 \times 10^{7}$ to $8.05 \times 10^{9} \mathrm{~m} / \mathrm{kg}$. The samples containing montmorillonite exhibited much poorer filterability.

Table 3. Average specific resistance of different slurry samples.

\begin{tabular}{ccc}
\hline Slurry Sample & $\begin{array}{c}\text { Components of Solid in Slurry } \\
\text { (Mass Fraction) }\end{array}$ & $\begin{array}{c}\text { Average Specific Resistance } \\
(\mathbf{m} / \mathbf{k g})\end{array}$ \\
\hline 1 & $100 \%$ coal & $1.98 \times 10^{7}$ \\
2 & $90 \%$ coal + 10\% kaolinite & $2.35 \times 10^{8}$ \\
3 & $80 \%$ coal + 20\% kaolinite & $3.68 \times 10^{8}$ \\
4 & $70 \%$ coal + 30\% kaolinite & $4.51 \times 10^{8}$ \\
5 & $98 \%$ coal + 2\% montmorillonite & $9.80 \times 10^{7}$ \\
6 & $95 \%$ coal + 5\% montmorillonite & $4.28 \times 10^{9}$ \\
7 & $90 \%$ coal + 10\% montmorillonite & $8.05 \times 10^{9}$ \\
\hline
\end{tabular}

\subsubsection{Porosity}

As shown in Figure 5, we cut the filter cake into three pieces, from top to bottom, named top layer, middle layer, and bottom layer, respectively. Figure 6 shows the porosity of different filter cakes. Due to the fine clay particles filling the pores formed by coarse coal particles, the porosity decreased with an increasing content of kaolinite and montmorillonite. For all cakes, the top layer showed the lowest porosity and the bottom layer showed the highest porosity. It was also the case that cakes containing montmorillonite showed a lower porosity than cakes containing kaolinite, especially for the top and middle layer. Low porosity could hinder the permeation of water through the cake and lead a poor filtration velocity. 


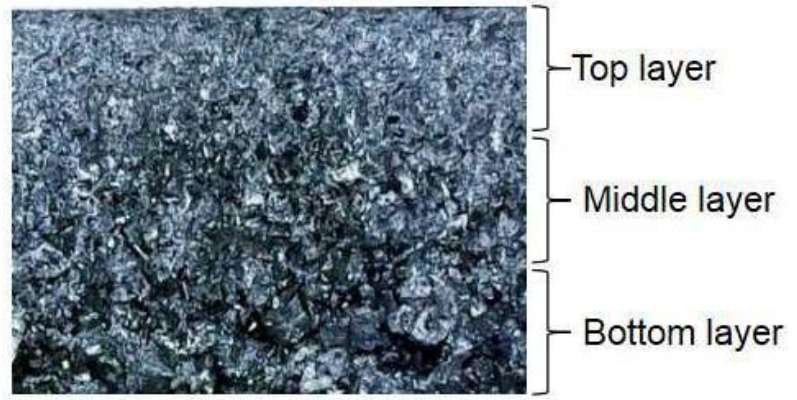

Figure 5. The longitudinal structure of the filter cake.

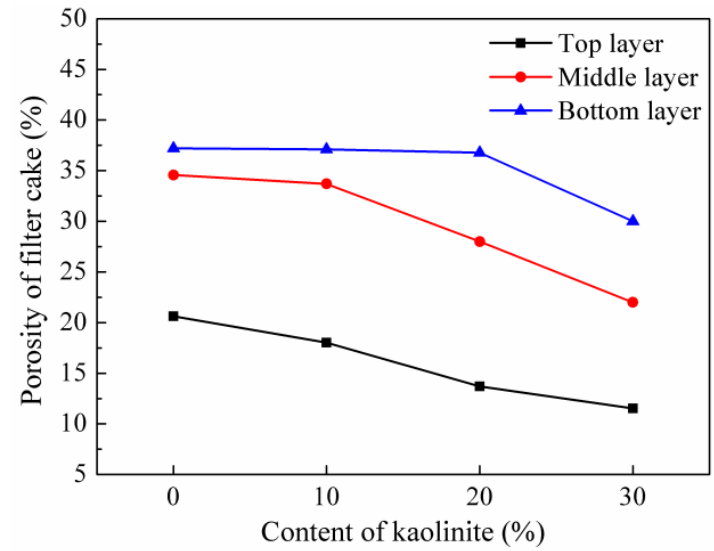

(a)

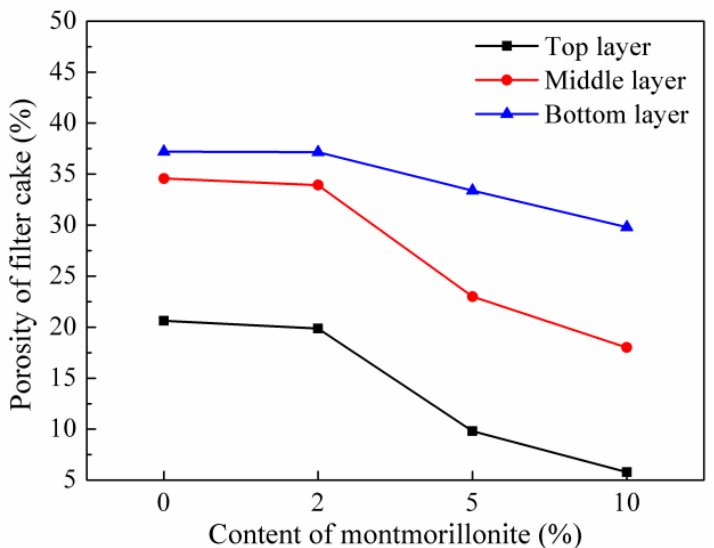

(b)

Figure 6. Porosity of the filter cake containing different contents of (a) kaolinite and (b) montmorillonite.

\subsubsection{Distribution of Clay Minerals}

The migration or distribution of clay minerals in the filter cake could help illustrate the deteriorative effect of clay minerals on the dewatering of coal slurry. The ash of raw coal is constant, so the ash content variation of cake is only caused by the existence of clay minerals. Hence, ash content analysis is used here to explore the distribution of clay minerals in the filter cake. Figure 7 presents the ash of different filter cakes. As shown in the figure, the cake containing no clay minerals had low and similar ash value in its three layers. However, for the cake containing clay minerals, there were clear variations in ash content. The high ash layers suggested a high concentration of clay minerals. Kaolinite was identified in all the layers as shown in Figure 7a. The ash content in all three layers increased with the increasing content of kaolinite. Most kaolinite existed in the top and middle layers of the filter cake. In the three cases containing montmorillonite, the results showed that most montmorillonite existed in the top layer, while a very limited amount of montmorillonite was identified in the bottom and middle layers, as shown in Figure $7 \mathrm{~b}$. The result indicates that the deteriorative effect of montmorillonite on the dewatering of slurry was mainly caused by its deposits on the top layer of the cake, greatly hindering the relative permeability of water.

\subsubsection{Distribution of Water}

Figure 8 presents the moisture distributions in filter cakes for different cases. The results show that the moisture in the top layer was usually higher than that in the middle and bottom layer in all cases. This was consistent with the distribution of clay minerals. In Figure 8, we also observe that the increase in moisture was small with increasing kaolinite compared with these cases with montmorillonite, while montmorillonite had a great influence on the moisture content of the filter cake. As the content of montmorillonite increased, the moisture of the filter cake increased sharply in all layers, as shown in Figure 8 b. 


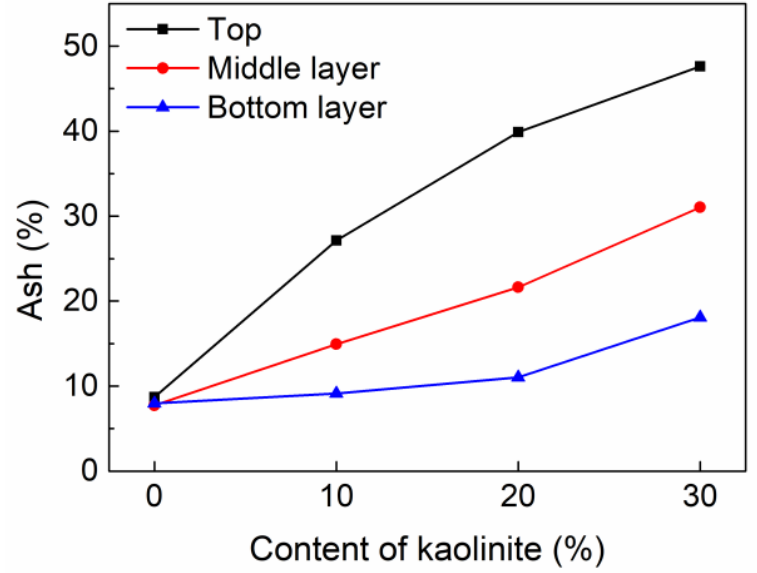

(a)

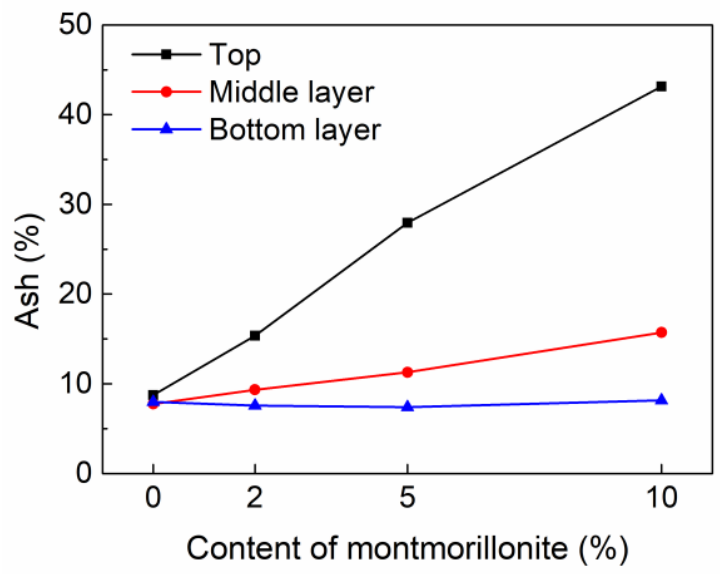

(b)

Figure 7. Ash in different parts of filter cakes for cases with different contents of (a) kaolinite and (b) montmorillonite.

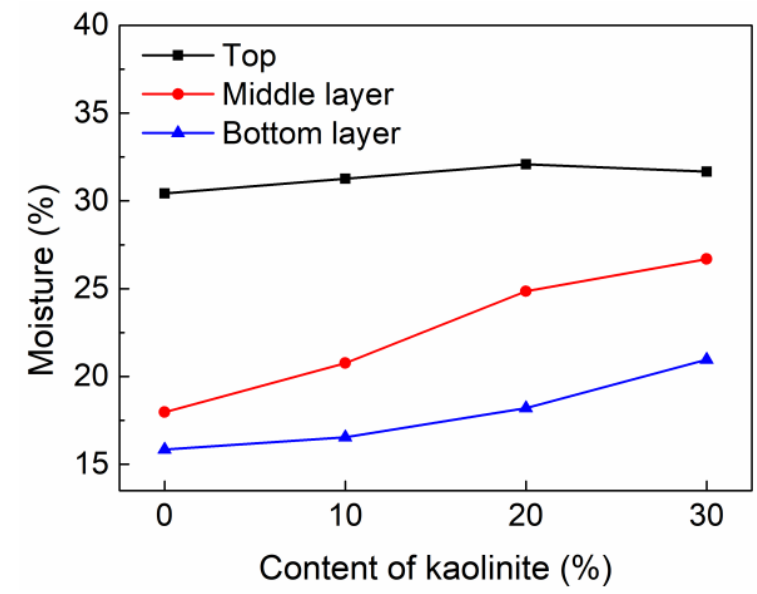

(a)

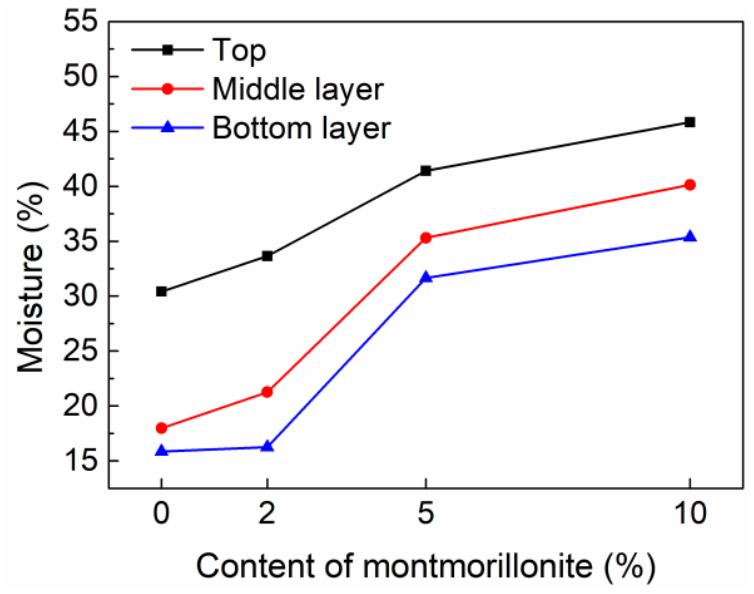

(b)

Figure 8. Moisture in different parts of filter cakes for cases with different contents of (a) kaolinite and (b) montmorillonite.

\subsection{Molecular Simulations Results}

\subsubsection{Adsorption of Water on the Side Surface of Kaolinite and Montmorillonite}

Figure 9 shows the equilibrium snapshot from an MD simulation of water adsorption on the side surface of kaolinite and montmorillonite. As shown in Figure 9a, in kaolinite, the tetrahedral silica sheet $(\mathrm{T})$ of one layer was always pointing to the octahedral alumina sheet $(\mathrm{O})$ of another layer. The hydroxyl group $(\mathrm{OH})$ on the $\mathrm{O}$ sheet and the oxygen atoms $(\mathrm{O})$ on the $\mathrm{T}$ sheet could form oxygen bonds. The interconnection between the layers was quite strong, which made the gap between layers short (about $2.05 \AA$ ). Therefore, water molecules were unable to enter the gap between kaolinite layers. Kaolinite could not suffer significant swelling behavior when dispersed in aqueous suspensions. Thus, in the dewatering experiment, the addition of kaolin had little effect on the moisture of the filter cake. For montmorillonite, the water molecules and hydrated cations could diffuse in the gaps between layers, as shown in Figure 9b. Therefore, montmorillonite in water could be highly dispersed by the swelling behavior and its permanent negative charge; this agrees with some previous reports [16,21]. The swelling behavior could result in difficulties in the penetration of water, which will affect the dewatering to a certain extent at the macro level [45]. 


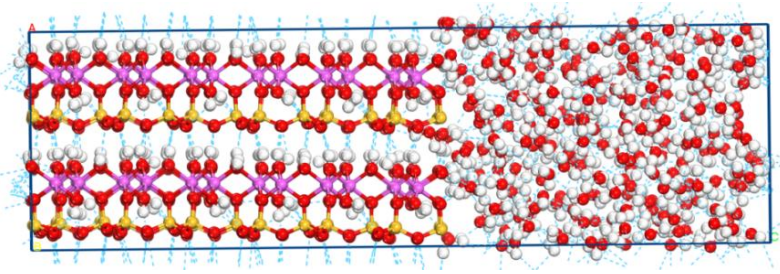

(a)

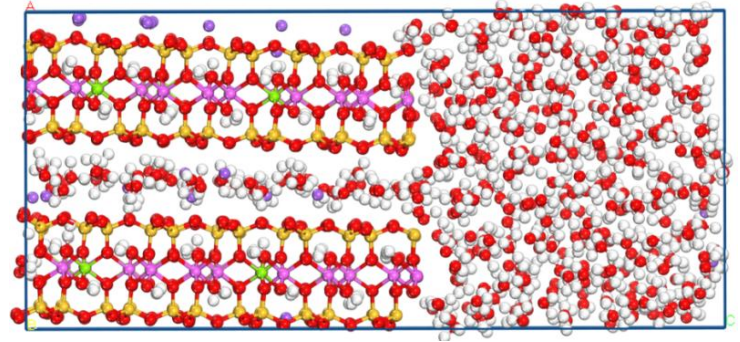

(b)

$$
\text { O-H } \quad \text { O-O } \quad \text { O-Si } \quad \text { O-Al } \quad \text { O-Na }
$$

Figure 9. Equilibrium snapshot from an MD simulation of water adsorption on the side surface of (a) kaolinite and (b) montmorillonite at $298 \mathrm{~K}$ and 1 bar.

\subsubsection{Swelling Curve of Montmorillonite}

To obtain the swelling curve of montmorillonite, supercell models consisting of four octahedral layers with a certain amount of water molecules packed in adjacent layers were built (an example is shown in Figure 10). Figure 11 presents the swelling curve of montmorillonite at $298 \mathrm{~K}$ and $1 \mathrm{~atm}$. The $d$-spacing of the dry montmorillonite was $9.47 \AA$. As the number of structural water molecules increased from 20 to 300 , the $d$-spacing showed linear growth increasing from $12.18 \AA$ to $21.20 \AA$. The overall swelling behavior of montmorillonite agrees well with the reported experimental studies $[46,47]$

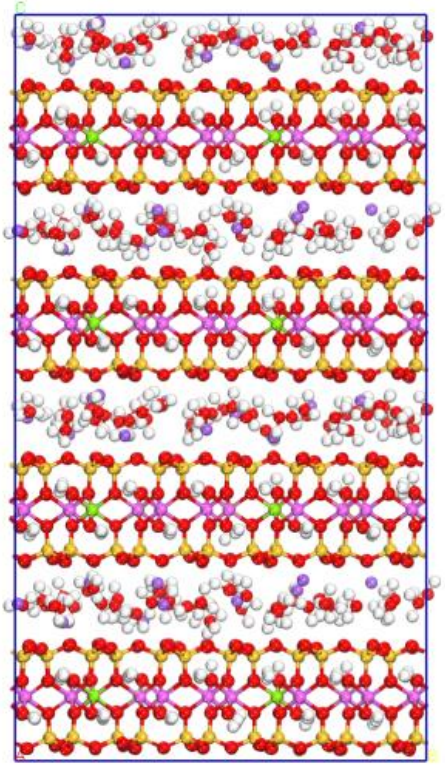

Figure 10. Equilibrium snapshot from an MD simulation of a montmorillonite supercell containing 50 structural water molecules in two neighboring layers at $298 \mathrm{~K}, 1$ bar. 


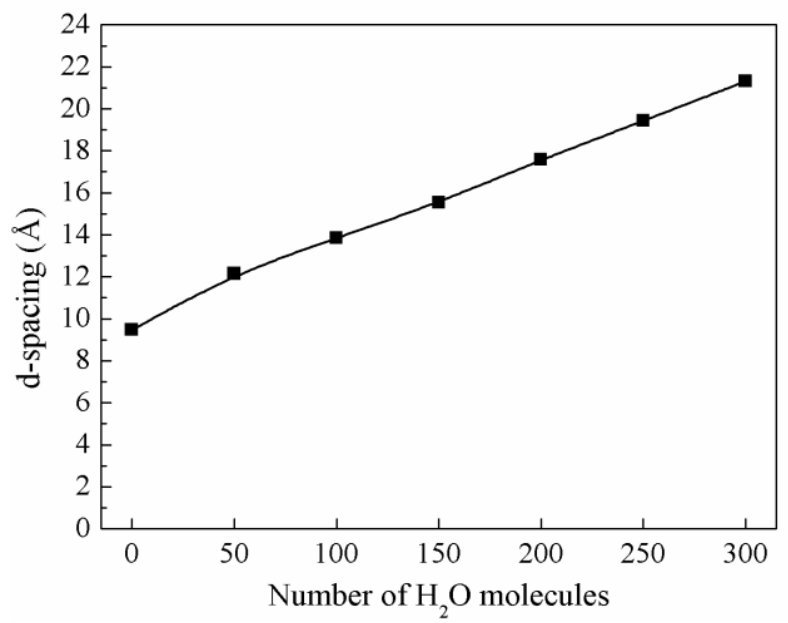

Figure 11. Swelling curve of montmorillonite: $d$-spacing as a function of the number of structural water molecules.

Figure 12 shows that water molecules had a certain orientation on the surface. Hydrogen atoms in water molecules were closer to the surface of montmorillonite, and the oxygen atoms were relatively far away from the surface, which caused the water molecules to exhibit an ordered distribution. When montmorillonite contains 100 structural water molecules, the water shows monolayer distribution, and the highest density was about $1 \mathrm{~g} / \mathrm{cm}^{3}$ (Figure 12a). When the number of water molecules was 200, the water showed a three-layer distribution. The density of the water layers close to the montmorillonite surface was $1.32 \mathrm{~g} / \mathrm{cm}^{3}$, and the density of the middle layer was about $1.1 \mathrm{~g} / \mathrm{cm}^{3}$ (Figure 12b). As the number of structural water molecules increased to 300, water showed a four-layer distribution. Water layers close to montmorillonite had a density of about $1.4 \mathrm{~g} / \mathrm{cm}^{3}$, and the density of two intermediate water layers was about $1.2 \mathrm{~g} / \mathrm{cm}^{3}$ (Figure 12c). Generally, the distance between the first water layer and the montmorillonite surface was $2 \AA$, and the distance between the first water layer and second water layer was $3 \AA$.
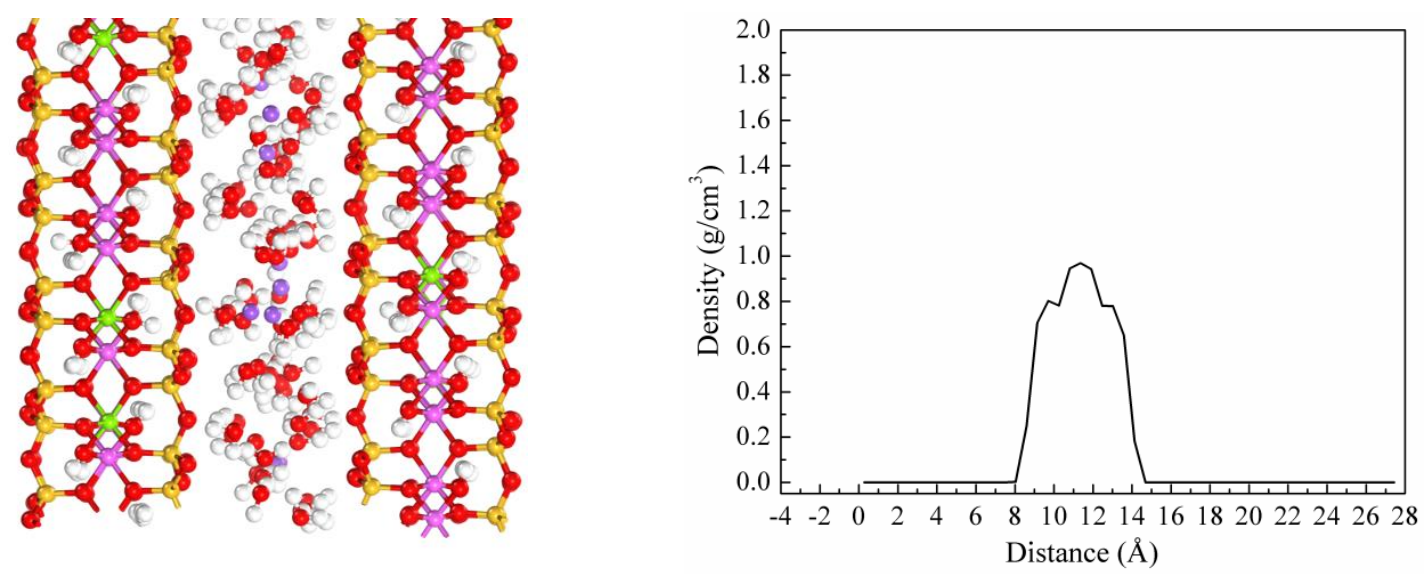

(a) Containing 100 structural water molecules

Figure 12. Cont. 

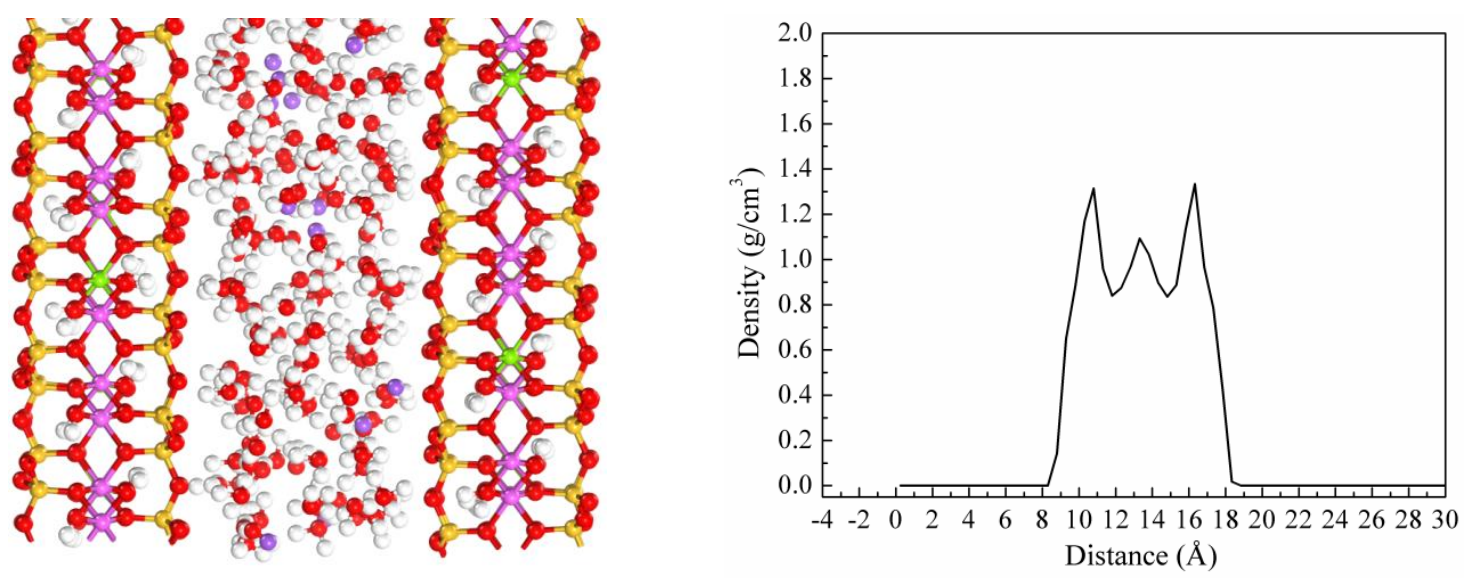

(b) Containing 200 structural water molecules
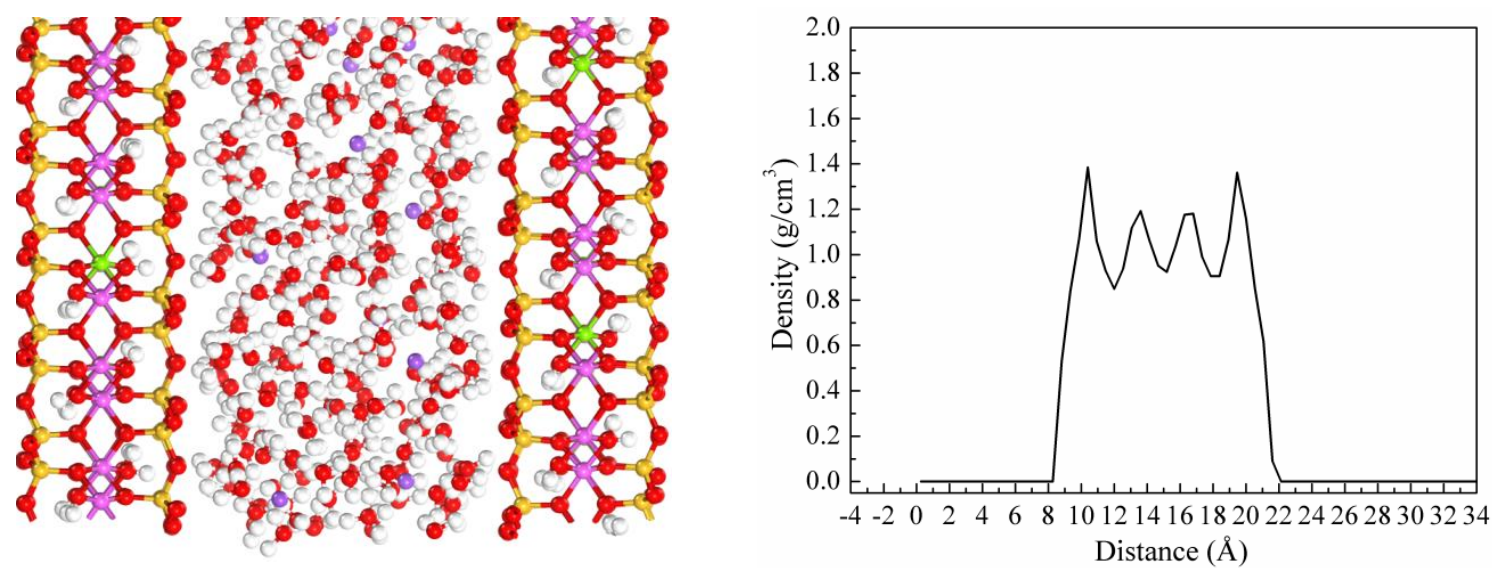

(c) Containing 300 structural water molecules

Figure 12. Structures and density distributions of water in montmorillonite layers containing (a) 100, (b) 200, and (c) 300 structural water molecules, respectively.

\subsubsection{Diffusion Coefficient}

The mean square displacement (MSD) and diffusion coefficient were calculated from the last 200 ps of the NVT simulation; the results are shown in Figure 13 and Table 4. The free diffusion coefficient of the water was $6.77 \times 10^{-5} \mathrm{~cm}^{2} / \mathrm{s}$. As shown in the figure, an increasing number of structural water molecules resulted in the decrease of the diffusion coefficients of water. The diffusion coefficient of water was only $0.63 \times 10^{-5} \mathrm{~cm}^{2} / \mathrm{s}$, with 100 structural water molecules placed in montmorillonite. This was caused by the strong interaction between water and the montmorillonite surface, which decreased the mobility of water. When the number of structural water molecules increased to 200 and 300, it exhibited a multi-layer distribution. The interaction between the montmorillonite surface and the middle layer of water was weaker than that of the water layer closer to the surface. Thus, the diffusion coefficient of water increased. However, even the diffusion coefficient of water, in the case of 300 structural water molecules, was quite low.

Table 4. Calculated diffusion coefficient of free water and structural water in montmorillonite.

\begin{tabular}{cc}
\hline Conditions & Diffusion Coefficient of Water $\left.\mathbf{( 1 0}^{-\mathbf{5}} \mathbf{c m}^{\mathbf{2}} \mathbf{s}\right)$ \\
\hline Free water molecules & 6.77 \\
300 structural water molecules & 2.40 \\
200 structural water molecules & 1.83 \\
100 structural water molecules & 0.63 \\
\hline
\end{tabular}




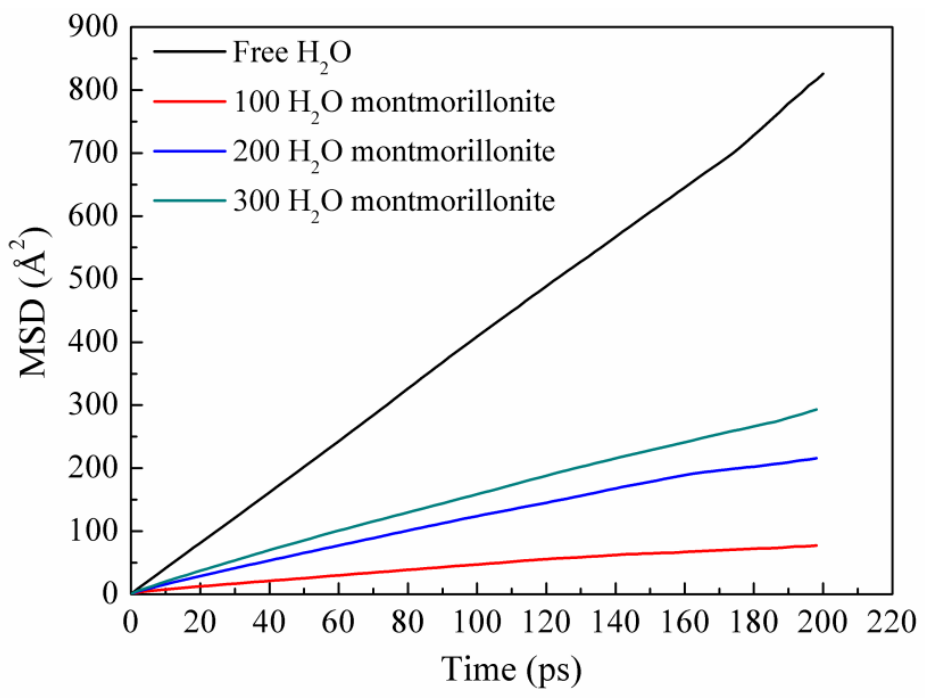

Figure 13. Mean square displacement (MSD) of free water and structural water in montmorillonite layers.

\subsubsection{Adsorption of Water on the Surfaces of Kaolinite and Montmorillonite}

In addition to the structural water, the adsorption of water on the surface of clay minerals was also related to the interaction between water and clay minerals. To compare the adsorption of the water on different clay surfaces, systems such as that in Figure 14 were established. Within the framework of this model, the number of water molecules filled between the two surfaces was 1200 with an initial density of $1 \mathrm{~g} / \mathrm{cm}^{3}$. The thickness of the vacuum layer added to the surface was $100 \AA$, and the statistical density distribution of water was collected from the last 200 ps of the NVT simulation.

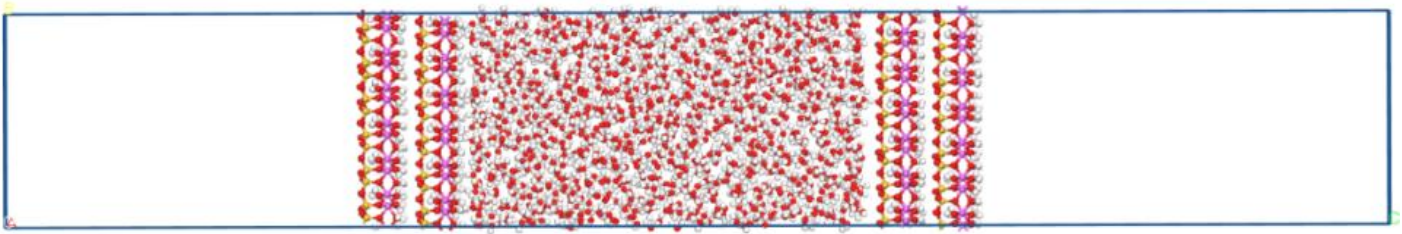

Figure 14. Model for an NVT simulation of water competitive adsorption on the T and O surface of kaolinite at $298 \mathrm{k}$.

The reported detailed distributions of water on the kaolinite surface vary because of the different force fields used. In this study, the results given by PCFF-INTERFACE force field showed that there were mainly three layers of water adsorbing on the $\mathrm{T}$ and $\mathrm{O}$ surface of kaolinite. The total thickness of these three layers of water was about $10 \AA$, as shown in Figure 15. The density of water $12 \AA$ from the surface was about $1 \mathrm{~g} / \mathrm{cm}^{3}$, indicating that this part of the water was less affected by the kaolinite surface. The peak density of water adsorbing on the octahedral alumina surface of kaolinite was $1.45 \mathrm{~g} / \mathrm{cm}^{3}$, which was higher than that of water adsorbing on the tetrahedral silica surface $\left(1.36 \mathrm{~g} / \mathrm{cm}^{3}\right)$. In addition, the adsorption distance between water and the $\mathrm{O}$ surface was smaller than that between water and the $\mathrm{T}$ surface. This was because of the hydrogen-bonding interaction between water and the -OH functional group on the octahedral surface. Therefore, the octahedral surface of kaolinite has a stronger affinity to water than the tetrahedral surface, which agrees well with the reported conclusion derived from binding the energy data of water with the double surfaces of kaolinite [48]. 


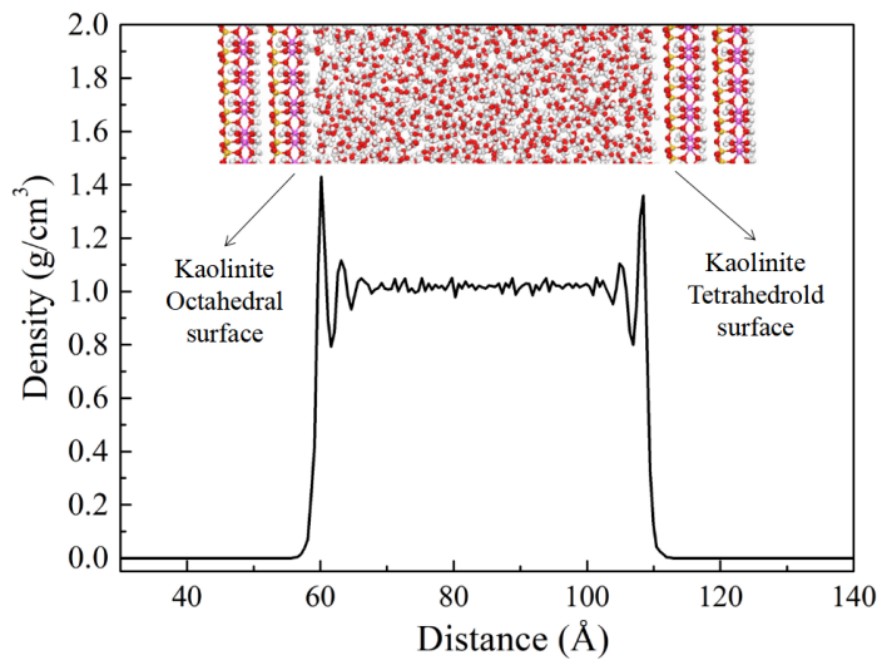

Figure 15. Density distribution of water on the $\mathrm{O}$ and $\mathrm{T}$ surface of kaolinite.

The adsorption of water on the kaolinite surface and the montmorillonite surface was also compared. Figure 16 demonstrates that the density of the first layer of water adsorbing on the surface of dry montmorillonite was $1.16 \mathrm{~g} / \mathrm{cm}^{3}$, but on the octahedral surface of kaolinite, the peak adsorption density of water was about $1.4 \mathrm{~g} / \mathrm{cm}^{3}$. This was because, in practice, there were usually several layers of water in montmorillonite. The density distributions of water adsorbing on the surface of montmorillonite hydrated with different amounts of water were also checked. The results indicated that the water content of montmorillonite had less effect on the adsorption of water on its surface. Kaolinite had less effect than montmorillonite on the filtration velocity and cake moisture in dewatering experiments. However, it is clear from Figure 17 that the density of water on the double surfaces of kaolinite was higher than that of water on montmorillonite. This result means that the effect of the water-swelling interaction on dewatering was much larger than that of the surface hydration interaction between water and clay minerals.

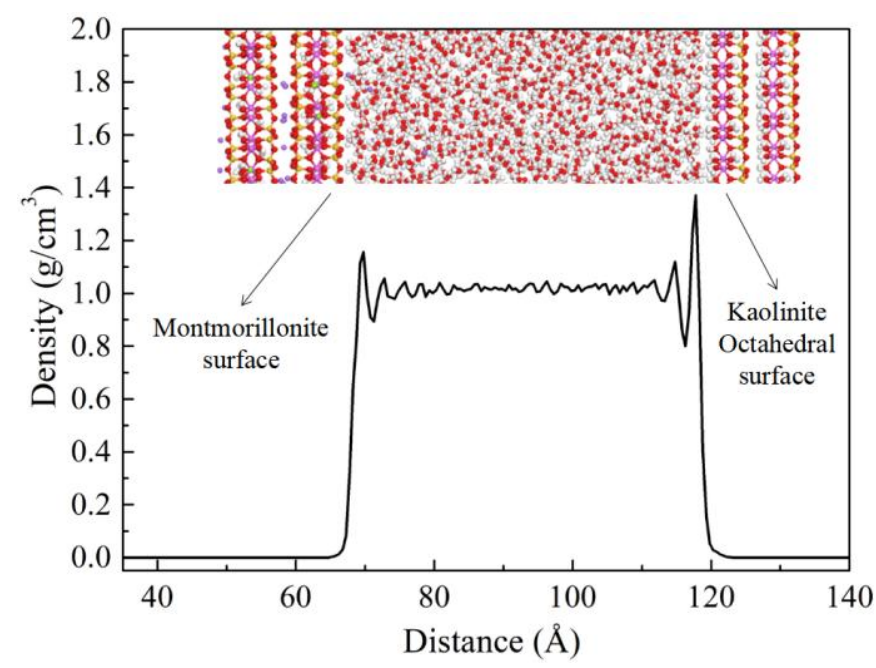

Figure 16. Density distribution of water on the surface of montmorillonite and the octahedron surface of kaolinite. 


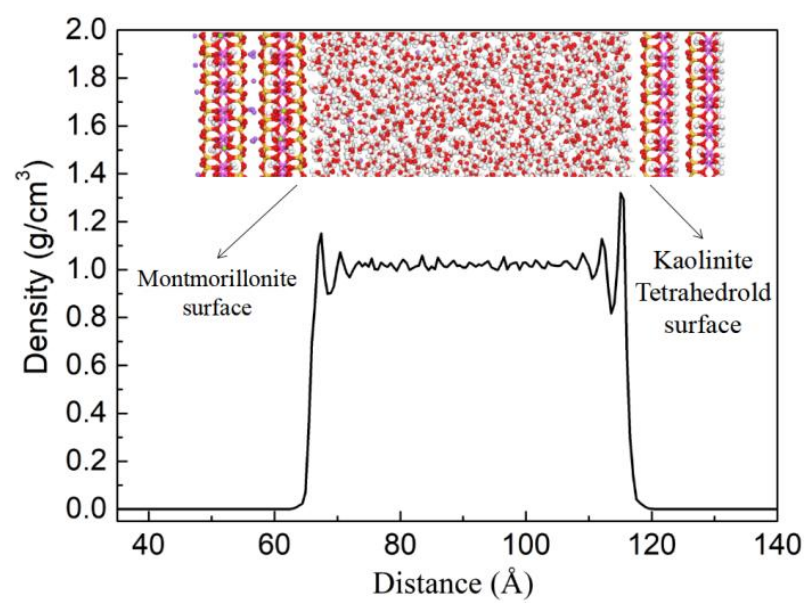

Figure 17. Density distribution of water on the surface of montmorillonite and the tetrahedron surface of kaolinite.

\section{Conclusions}

In this study, we investigated the effect of kaolinite and montmorillonite on the dewatering of coal tailings by filtration experiments. Then, water-kaolinite/montmorillonite interactions were analyzed by conducting molecular simulations. The main conclusions obtained from this study are summarized as follows:

(1) The efficiency of the dewatering process was significantly reduced by kaolinite and montmorillonite. However, montmorillonite had much more influence than kaolinite. A small amount of montmorillonite contributed to a significant reduction in the filtration velocity and a high increase in the moisture of the filter cake. This result indicates that the interaction between kaolinite/montmorillonite and water played a key role in the efficiency of the dewatering process.

(2) Most kaolinite existed in the top and middle layers of the filter cake. Most montmorillonite existed in the top layer of the filter cake, while a very limited amount of montmorillonite was identified in the bottom and middle layers of the filter cake.

(3) Water molecules could hardly diffuse into kaolinite from the edge, but could easily spread into the montmorillonite layers from the edge surface because of the existence of a hydrated cation in montmorillonite and a weak interlayer connection. Structural water molecules in montmorillonite have a low diffusion coefficient, which hindered the dewatering effectiveness.

(4) The density of water on the double surfaces of kaolinite was higher than that of water on montmorillonite. This result meant that the effect of the water-swelling interaction on dewatering was much greater than that of the surface hydration interaction between water and clay minerals

Author Contributions: Methodology, X.M.; Software, X.M.; Investigation, X.M.; Writing-Original Draft, X.M.; Supervision, X.D.; Funding Acquisition, Y.F.; Conceptualization, Y.F.; Project administration, Y.F.; Formal analysis, R.C.; Data curation, R.C.; Resources, H.L.; Validation, D.S.; Visualization, S.Y.

Funding: This research was funded by National Natural Science Foundation of China grant number 51674174, Natural Science Youth Foundation of China grant number 51604189, and Natural Science Foundation of Shanxi Province grant number 201601D011056.

Acknowledgments: The authors would like to thank the Canadian Center for Clean Coal/Carbon and Mineral Processing Technologies (C5MPT). The authors also thank Yueliang Liu and Yingkun Fu at the University of Alberta for their help with this paper.

Conflicts of Interest: The authors declare no conflict of interest.

\section{References}

1. Devasahayam, S.; Ameen, M.A.; Verheyen, T.V.; Bandyopadhyay, S. Brown coal dewatering using poly (acrylamide-co-potassium acrylic) based super absorbent polymers. Minerals 2015, 5, 623-636. [CrossRef] 
2. Hogg, R. Flocculation and dewatering. Int. J. Miner. Process. 2000, 58, 223-236. [CrossRef]

3. Kretser, D.R.; Scales, P.J.; Boger, D.V. Improving clay-based tailings disposal: Case study on coal tailings. AIChE J. 1997, 43, 1894-1903. [CrossRef]

4. Sabah, E.; Yüzer, H.; Celik, M.S. Characterization and dewatering of fine coal tailings by dual-flocculant systems. Int. J. Miner. Process. 2004, 74, 303-315. [CrossRef]

5. Wang, C.; Harbottle, D.; Liu, Q.X.; Xu, Z.H. Current state of fine mineral tailings treatment: A critical review on theory and practice. Miner. Eng. 2014, 58, 113-131. [CrossRef]

6. Liu, H.B.; Liu, Z.L. Recycling utilization patterns of coal mining waste in China. Resour. Conserv. Recycl. 2010, 54, 1331-1340. [CrossRef]

7. Jang, M.; Lee, H.J.; Shim, Y. Rapid removal of fine particles from mine water using sequential processes of coagulation and flocculation. Environ. Technol. 2010, 31, 423-432. [CrossRef] [PubMed]

8. Salmachi, A.; Karacan, C.Ö. Cross-formational flow of water into coalbed methane reservoirs: Controls on relative permeability curve shape and production profile. Environ. Earth Sci. 2017, 76, 200. [CrossRef] [PubMed]

9. Nghiem, L.D.; Ren, T.; Aziz, N.; Porter, I.; Regmi, G. Treatment of coal seam gas produced water for beneficial use in Australia: A review of best practices. Desalin. Water Treat. 2011, 32, 316-323. [CrossRef]

10. Hamawand, I.; Yusaf, T.; Hamawand, S.G. Coal seam gas and associated water: A review paper. Renew. Sustain. Energy Rev. 2013, 22, 550-560. [CrossRef]

11. Li, S.L.; Liao, Y.F.; Li, G.S.; Li, Z.; Cao, Y.J. Flocculating and dewatering performance of hydrophobic and hydrophilic solids using a thermal-sensitive copolymer. Water Sci. Technol. 2017, 76, 694-704. [CrossRef] [PubMed]

12. Salmachi, A.; Talemi, P.; Tooski, Z.Y. Psyllium husk in water-based drilling fluids: An environmentally friendly viscosity and filtration agent. In Proceedings of the Abu Dhabi International Petroleum Exhibition \& Conference. Society of Petroleum Engineers, Abu Dhabi, UAE, 7-10 November 2016. [CrossRef]

13. Gao, Z.Y.; Li, C.W.; Sun, W.; Hu, Y.H. Anisotropic surface properties of calcite: A consideration of surface broken bonds. Colloids Surf. A. 2018, 520, 53-61. [CrossRef]

14. Murray, H.H. Structure and composition of the clay minerals and their physical and chemical properties. Dev. Clay Sci. 2006, 2, 7-31. [CrossRef]

15. Azeez, A.A.; Rhee, K.Y.; Park, S.J.; Hui, D. Epoxy clay nanocomposites-Processing, properties and applications: A review. Compos. Part B Eng. 2013, 45, 308-320. [CrossRef]

16. Zhang, X.; Yi, H.; Zhao, Y.L.; Min, F.F.; Song, S.X. Study on the differences of Na-and Ca-montmorillonites in crystalline swelling regime through molecular dynamics simulation. Adv. Powder Technol. 2016, 27, 779-785. [CrossRef]

17. Li, H.; Song, S.X.; Dong, X.S.; Min, F.; Zhao, Y.; Peng, C.; Nahmad, Y. Molecular dynamics study of crystalline swelling of montmorillonite as affected by interlayer cation hydration. JOM 2018, 70, 479-484. [CrossRef]

18. Sun, L.; Hirvi, J.T.; Schatz, T.; Kasa, S.; Pakkanen, T.A. Estimation of montmorillonite swelling pressure: A molecular dynamics approach. J. Phys. Chem. C 2015, 119, 19863-19868. [CrossRef]

19. Amarasinghe, P.M.; Katti, K.S.; Katti, D.R. Insight into role of clay-fluid molecular interactions on permeability and consolidation behavior of Na-montmorillonite swelling clay. J. Geotech. Geoenviron. Eng. 2011, 138, 138-146. [CrossRef]

20. Mpofu, P.; Addai-Mensah, J.; Ralston, J. Interfacial chemistry, particle interactions and improved dewatering behaviour of smectite clay dispersions. Int. J. Miner. Process. 2005, 75, 155-171. [CrossRef]

21. Foster, M.D. The relation between composition and swelling in clays. Clay Clay Min. 1954, 3, $205-220$. [CrossRef]

22. Segad, M.; Jonsson, B.; Åkesson, T.; Cabane, B. Ca/Na montmorillonite: Structure, forces and swelling properties. Langmuir 2010, 26, 5782-5790. [CrossRef] [PubMed]

23. Segad, M.; Hanski, S.; Olsson, U.; Ruokolainen, J.; Åkesson, T.; Jonsson, B.G. Microstructural and swelling properties of $\mathrm{Ca}$ and Na montmorillonite:(in situ) observations with cryo-TEM and SAXS. J. Phys. Chem. C 2012, 116, 7596-7601. [CrossRef]

24. McFarlane, A.; Bremmell, K.; Addai-Mensah, J. Improved dewatering behavior of clay minerals dispersions via interfacial chemistry and particle interactions optimization. J. Colloid Interface Sci. 2006, 293, 116-127. [CrossRef] [PubMed] 
25. Anderson, R.L.; Ratcliffe, I.; Greenwell, H.C.; Williams, P.A.; Cliffe, S.; Coveney, P.V. Clay swelling-A challenge in the oilfield. Earth-Sci. Rev. 2010, 98, 201-216. [CrossRef]

26. Zhang, H.Y.; Kuang, Y.L.; Wang, G.H.; Ji, L. Soft sensor model for coal slurry ssh content based on image gray characteristics. Int. J. Coal Prep. Util. 2014, 34, 24-37. [CrossRef]

27. Ofori, P.; Nguyen, A.V.; Firth, B.; McNally, C.; Ozdemir, O. Shear-induced floc structure changes for enhanced dewatering of coal preparation plant tailings. Chem. Eng. J. 2011, 172, 914-923. [CrossRef]

28. Mukherjee, S. Environmental impacts of clay-related industries. In The Science of Clays; Springer: Dordrecht, The Netherlands, 2013; pp. 280-295.

29. Rong, R.X.; Hitchins, J. Preliminary study of correlations between fine coal characteristics and properties and their dewatering behaviour. Miner. Eng. 1995, 8, 293-309. [CrossRef]

30. Hussain, S.A.; Demirci, S..; Özbayoğlu, G. Zeta potential measurements on three clays from Turkey and effects of clays on coal flotation. J. Colloid Interface Sci. 1996, 184, 535-541. [CrossRef] [PubMed]

31. Alam, N.; Ozdemir, O.; Hampton, M.A.; Nguyen, A.V. Dewatering of coal plant tailings: Flocculation followed by filtration. Fuel 2011, 90, 26-35. [CrossRef]

32. Dong, X.S.; Hu, X.J.; Yao, S.L.; Peng, W.R.; Wang, Z.Z. Vacuum filter and direct current electro-osmosis dewatering of fine coal slurry. Procedia Earth Planet. Sci. 2009, 1, 685-693. [CrossRef]

33. Dong, X.S.; Feng, L.H.; Yao, S.L.; Niu, D.F. Study on dewatering of fine coal by combination of electrolysis and filtration. Adv. Mater. Res. 2011, 236, 622-626. [CrossRef]

34. Min, F.F.; Peng, C.L.; Liu, L.Y. Investigation on hydration layers of fine clay mineral particles in different electrolyte aqueous solutions. Powder Technol. 2015, 283, 368-372. [CrossRef]

35. Gui, X.; Liu, J.; Cao, Y.; Miao, Z.; Li, S.; Xing, Y.; Wang, D. Coal preparation technology: Status and development in China. Energy Environ. 2015, 26, 997-1013. [CrossRef]

36. Heinz, H.; Lin, T.J.; Mishra, R.K.; Emami, F.S. Thermodynamically consistent force fields for the assembly of inorganic, organic, and biological nanostructures: The interface force field. Langmuir 2013, 2, 1754-1765. [CrossRef] [PubMed]

37. Fan, Y.P.; Dong, X.S.; Li, H. Dewatering effect of fine coal slurry and filter cake structure based on particle characteristics. Vacuum 2015, 114, 54-57. [CrossRef]

38. Ruth, B.F. Correlating filtration theory with industrial practice. Ind. Eng. Chem. 1946, 38, 564-571. [CrossRef]

39. Mota, M.; Teixeira, J.A.; Yelshin, A. Influence of cell-shape on the cake resistance in dead-end and cross-flow filtrations. Sep. Purif. Technol. 2002, 27, 137-144. [CrossRef]

40. Gamba, M.; Kovář, P.; Pospíšil, M.; Sánchez, R.M.T. Insight into thiabendazole interaction with montmorillonite and organically modified montmorillonites. Appl. Clay Sci. 2017, 137, 59-68. [CrossRef]

41. Bragg, W.H.; Bragg, W.L. The X-Ray spectrometer. Nature 1914, 94, 199-200. [CrossRef]

42. Schoen, M.; Hoheisel, $C$. The mutual diffusion coefficient $\mathrm{D}_{12}$ in binary liquid model mixtures. Molecular dynamics calculations based on Lennard-Jones (12-6) potentials. Mol. Phys. 1984, 52, 1029-1042. [CrossRef]

43. Chang, I.L.; Chu, C.P.; Lee, D.J.; Huang, C.P. Expression dewatering of alum-coagulated clay slurries. Environ. Sci. Technol. 1997, 31. [CrossRef]

44. Zhang, Y.; Gong, G.Q.; Wu, G.G.; Wang, Y.L. Physical properties and filter cake structure of fine clean coal from flotation. Int. J. Min. Sci. Technol. 2014, 24, 281-284. [CrossRef]

45. Mpofu, P.; Addai-Mensah, J.; Ralston, J. Flocculation and dewatering behaviour of smectite dispersions: Effect of polymer structure type. Miner. Eng. 2004, 17, 411-423. [CrossRef]

46. Teich-McGoldrick, S.L.; Greathouse, J.A.; Jove-Colon, C.F.; Cygan, R.T. Swelling properties of montmorillonite and beidellite clay minerals from molecular simulation: Comparison of temperature, interlayer cation, and charge location effects. J. Phys. Chem. C 2015, 119, 20880-20891. [CrossRef]

47. Vao-soongnern, V.; Pipatpanukul, C.; Horpibulsuk, S. A combined X-ray absorption spectroscopy and molecular dynamic simulation to study the local structure potassium ion in hydrated montmorillonite. J. Mater. Sci. 2015, 50, 7126-7136. [CrossRef]

48. Croteau, T.; Bertram, A.K.; Patey, G.N. Simulation of water adsorption on kaolinite under atmospheric conditions. J. Phys. Chem. A 2009, 113, 7826-7833. [CrossRef] [PubMed]

(C) 2018 by the authors. Licensee MDPI, Basel, Switzerland. This article is an open access article distributed under the terms and conditions of the Creative Commons Attribution (CC BY) license (http:/ / creativecommons.org/licenses/by/4.0/). 